\section{REGENERAÇÃO E \\ RESILIÊNCIA: AS \\ INTERVENÇÕES URBANAS \\ RECENTES NA PRACA \\ ROOSEVELT EM SÃO PAULO}

\author{
Marlon Paiva ${ }^{1}$ y Maria Cristina da Silva \\ Schicchi
}

\section{Resumo}

Este artigo apresenta algumas considerações sobre a definição dos conceitos de regeneração e de resiliência urbana, a partir de uma revisão da literatura científica de ambos os termos e uma discussão sobre a possibilidade de aplicação das respectivas leituras no contexto de intervenções urbanas recentes empreendidas no centro histórico de São Paulo (2010-2012). Recorre à leitura dos dois processos e seus fenômenos associados em ações de intervenção urbana que visam a renovação de espaços públicos, adotando como caso de estudo eespecífico a Praça Roosevelt, na área central

\section{REGENERATION AND RESILIENCE: RECENTE URBAN INTERVENTIONS AT ROOSEVELT SQUARE IN SÃO PAULO}

\author{
Marlon Paiva y Maria Cristina da Silva \\ Schicchi
}

\section{Abstract}

This article presents some considerations on the definition of the concepts of urban regeneration and resilience, based on a review of the scientific literature of both terms and a discussion on the possibility of applying the respective readings in the context of recent urban interventions undertaken in the historic center of São Paulo (2010-2012). It uses the reading of the two processes and their associated phenomena in urban intervention actions aimed at the renovation of public spaces, adopting as a specific case study the Roosevelt Square, in the downtown area. As a result, we 
da capital paulista. Como resultados, buscase verificar como tais questões se manifestam no território estudado, de modo a verificar as repercussões de tais processos nas formas de uso e apropriação da praça, em distintos períodos.

\section{PALAVRAS-CHAVE: REGENERAÇÃO URBANA RESILIÊNCIA, PLANEJAMENTO URBANO, ESPAÇOS PÚBLICOS, SÃO PAULO.}

Recebido: 2020-03-31

Aceito: 2020-09-02 seek to verify how such issues are manifested in the studied territory, in order to verify the repercussions of such processes in the forms of use and appropriation of the square, in different periods.

\section{KEYWORDS: URBAN REGENERATION, RESILIENCE, URBAN PLANNING, PUBLIC SPACES, SÃO PAULO.}

Received: 2020-03-31

Accepted: 2020-09-02

1 Doutorando do Programa de Pós-Graduação em Arquitetura e Urbanismo da Pontifícia Universidade Católica de Campinas - São Paulo, Brasil, http://orcid.org/0000-0001-92060788. Endereço eletrônico: marlon.paiva@puc-campinas. edu.br

2 Professora titular e pesquisadora do Programa de Pós-Graduação em Arquitetura e Urbanismo da Pontifícia Universidade Católica de Campinas - São Paulo, Brasil, https://orcid.org/00000002-4267-2601. Endereço eletrônico: cristina.schicchi@ puc-campinas.edu.br 


\section{Introdução}

A perspectiva de uma crise urbana permanente e a busca por fomentar o desenvolvimento econômico a partir de intervenções em áreas consolidadas, tornaram-se um capítulo a mais nos processos de geração de desigualdades e tensõessociais. Por outrolado, as transformações ininterruptas das grandes metrópoles, bem como a fluidez e transitoriedades próprias de seus espaços públicos, exigem um permanente alerta quanto às formas de apropriação e reprodução dos espaços da cidade.

Neste contexto, nos últimos vinte anos, as diferentes propostas e ações apresentadas pelo Estado - no sentido do desenho e/ou redesenho de espaços públicos visando atribuir um maior dinamismo em seus territórios - concentraram-se em definir estratégias para a solução de problemas locais, como os que decorrem de obsolescências urbanas. Em contraposição, surgem novos arranjos sociais, como a formação de coletivos e de processos participativos, assim como profissionais, com a criação de equipes multidisciplinares, no sentido de compreender diferentes necessidades e conflitos, desenvolver novas possibilidades de atuação e refletir sobre tendências na apropriação e uso dos espaços públicos.

Este artigo propõe um olhar sobre o centro histórico da cidade de São Paulo, onde as propostas de "reúso" de seus espaços públicos, assim como seus redesenhos contemporâneos, induziram a estruturação de processos de regeneração urbana, materializados através de ações concertadas e de caráter fortemente estratégico, que visam melhorias a curto, médio e longo prazo nos espaços, objetos de intervenções urbanas.

Especificamente, foi selecionado um objeto de estudo que, sendo um espaço público, objeto de intervenção recente, apresenta os elementos essenciais que possibilitam ilustrar as questões apresentadas: a Praça Franklin Delano Roosevelt.

Contudo, contradições são geradas a partir de intervenções realizadas pelo Estado, quando desenhadas de maneira genérica e orientadas pelo capital no sentido de criar garantias de retorno dos investimentos econômicos - em detrimento do social. Tais intervenções acabam se distanciando das diversas realidades locais, e podem induzir o desenvolvimento de uma série de conflitos, que se expressam nas mudanças de uso e ocupação do solo, nos deslocamentos de populações, bem como pela intensificação do fenômeno da gentrificação, entre outros. O termo, inicialmente discutido por Ruth Glass, em 1964, refere-se a

"(...) los cambios en el mercado laboral y la estrutura social vinculados a la emergencia de una economia pos industrial. La aparición de una clase vinculada a los servicios de esta nueva economía es la base material que da sustento a nuevos estilos de vida, patrones culturales y de consumo que tienen en la gentrificación una de sus principales expresiones urbanas" (Guevara, 2015, p. 13). 
Desta forma, surge a necessidade da ampliação de estudos que promovam um debate amplo, novas abordagens e métodos que apoiem futuras políticas, projetos e práticas de gestão, no sentido de compreender os conflitos que se produzem nos territórios locais atingidos por essas intervenções. É nesse sentido que adotase um outro conceito, o de resiliência urbana, que permite dimensionar a capacidade de uma comunidade de antecipar, prever e mitigar os perigos, aproveitando as oportunidades advindas das mudanças ambientais e sociais decorrentes de uma ação ou intervenção, de maneira a satisfazer as novas necessidades surgidas (Holling, 1973).

À luz destes dois conceitos, adotados por motivos distintos, o primeiro para descrever e enquadrar as intervenções ocorridas nos últimos vinte anose o segundo para a compreensão do espaço-tempo vivido no território já configurado, tem-se como objetivo geral elaborar uma breve análise das políticasurbanas paulistanas, sobretudo daquelas adotadas nas intervenções de requalificação urbana em centros históricos, que constituem lugares em constante transformação. A análise do fenômeno de resiliência urbana apresentase como instrumento, ou mesmo um indicador, para medir os efeitos do modelo dominante de produção da cidade contemporânea.

Desta forma, o artigo está organizado a partir de três abordagens. Primeiramente, discutemse os conceitos de regeneração e resiliência urbana, sistematizados a partir de uma revisão bibliográfica sobre a origem dos dois termos e seus usos, em distintos momentos, por meio de autores como Fantova, 2008; Farias, 2017; Gonçalves, 2016; Holling, 1973, 2001; Ojeda, 2004; Silva, 2014

Num segundo momento, busca-se avaliar a possibilidade de utilizar a análise dos processos de resiliência como ferramenta para a leitura dos usos e apropriações presentes no território. Por fim, procura-se traduzir essa possibilidade de leitura num território consolidado, concentrando-se na leitura do caso do espaço público citado.

\section{A regeneração urbana: definição e características}

A partir dos anos 1950, a atividade de planejamento cresceu significativamente, evoluindo de planos utópicose/ou voltados paraa habitação social para a concreta implementação de programas que se estabeleciam dentro do aparelho político envolvido por agendas econômicas. O discurso dominante sobre o planejamento, com seus programas de desenvolvimento e redesenvolvimento urbanos, era o de que consistia numa atividade inequivocamente beneficente de governo: abrangente, tecnocrática, científica e socialmente progressiva, reformando as cidades para permanecerem mais saudáveis, eficientes, prósperas e bonitas (Freestone, 2015). 
Os alvos desses programas eram lugares obsoletos das cidades, usualmente - mas nem sempre - áreas bombardeadas ou destruídas pela guerra, para estabelecer novos usos que fossem ao encontro das necessidades da 'moderna' cidade industrial, com impactos nos tecidos históricos das cidades e nas comunidades existentes. No caso específico da cidade de São Paulo, as iniciativas de desenvolvimento urbano frequentemente buscaram espaços previamente urbanizados, vantajosos e convenientes para implantar, ou reimplantar melhorias visando o crescimento econômico.

Nas últimas décadas do séc. XX, começa a surgir uma nova política urbana que procura a requalificação da cidade existente a partir de um planejamento de caráter fortemente estratégico, que irá produzir múltiplas formas de intervenção e abarcar um conjunto de ações concertadas e determinadas a potencializar os valores socioeconômicos, ambientais e funcionais de determinados territórios com a finalidade da melhoria de vida das suas populações residentes: a regeneração urbana (Mendes, 2013).

A regeneração resulta da relação entre as forças internas e externas envolvidas nas operações, que estabelecem a necessidade de uma constante adaptação e uma resposta aos desafios e oportunidades que, num determinado contexto temporal e espacial, podem resultar da degradação urbana (Mendes, 2013). Além disso, se apresenta como uma política pública capaz de introduzir intervenções positivas visando a solução de problemas específicos em áreas urbanas consolidadas, ou em novas áreas surgidas a partir da expansão urbana (Shurmersmith e Burtnenshaw, 1994 como citado em Mendes, 2013, p. 35).

Por outro lado, cabe ressaltar que a ideia de regeneração urbana não constitui um fenômeno novo. De acordo com Mendes (2013), sobretudo nos países mais desenvolvidos, a regeneração já consistia em uma maneira de pensar e produzir o espaço urbano.

Após as demolições decorrentes dos conflitos da Segunda Guerra Mundial, como na Inglaterra e na Alemanha, foi necessária a reconstrução de vários espaços urbanos. Essa situação abriu caminho a profundas modificações na política urbana europeia, e para os trabalhos de reconstrução foram iniciadas tanto operações de renovação ${ }^{3}$ quanto de restauração ${ }^{4}$ e reabilitação ${ }^{5}$ urbana. Apesar desses antecedentes, foi a partir

3 A renovação urbana objetiva a alteração global do conjunto edificado existente e a substituição por novas construções voltadas para os mesmos usos ou diferentes, respeitando-se o caráter dos edifícios e propondo a atuação no tecido social (Fernandes da Cruz, 2015, p.79).

4 Restauração é uma intervenção na preexistência que objetiva, unicamente, restabelecer a unidade artística plena da obra, não redefinido seu caráter figurativo, não interferindo na imagem que ainda é apreendida, e também não comprometendo a legitimidade artística e histórica do monumento (Brandi, 2004, p. 14)

5 A reabilitação urbana objetiva a manutenção do caráter arquitetônico dos edifícios e suas funções originais, abrangendo variadas formas de intervenção que podem ir da simples recuperação do edificado e dos espaços públicos 
do final da década de 1970 que o conceito de regeneração urbana começou a se difundir em países como o Reino Unido, França, Espanha e Holanda, surgindo como contraponto à renovação urbana, que privilegiava sobretudo novas intervenções físicas no espaço urbano.

Nos anos 1980-90, as políticas de regeneração urbana firmaram-se como um dos principais instrumentos para recuperação de áreas consolidadas das cidades. Reconhecia-se nas áreas urbanas abandonadas ou em processo de declínio, uma oportunidade para atrair investimentos privados e garantir a reprodução do capital imobiliário. Desse modo, evidenciase o papel de relevo do marketing urbano na gestão estratégica da imagem das cidades, de forma a evidenciar diferenças entre elas, bem como valorizá-las e projetá-las no contexto internacional (Barata Salgueiro, 2005).

Um exemplo emblemático desse processo ocorreu no final da década de 1980, durante a preparação dos Jogos Olímpicos de Barcelona de 1992, que foram precedidos por um conjunto de intervenções na cidade, uma das mais conhecidas operações de regeneração urbana europeias. Sendo uma cidade com um setor industrial bastante relevante, Barcelona decidiu reconverter todo o espaço industrial e portuário que se localizava ao longo da costa, abrindo a cidade novamente para o mar. Com a realização

a ações mais abrangentes de revitalização social e econômica (Fernandes da Cruz, 2015, p. 83). dos Jogos Olímpicos, a cidade conheceu outro fulgor, que a projetou como uma das cidades mais visitadas no continente europeu. Este seria também um dos principais casos em que a regeneração urbana se relacionaria com grandes eventos, que conseguiram capitalizar a sociedade civil para novos desafios e uma nova imagem urbana (Tallon, 2010).

\section{A resiliência urbana: definição e características}

A partir de meados do século XX, a noção de resiliência, que tradicionalmente estava associada a determinados campos da ciência como a biologia, a engenharia e a física, passou a ser introduzida em áreas como a das ciências humanas e ambientais, dentro de uma visão modernista e progressista. Neste sentido, a partir dos anos 1970, foi possível a aplicação do conceito para a leitura de impactos decorrentes dos fenômenos urbanos e ambientais, passando a se relacionar aos contextos de economia urbana e sistemas ambientais demandados por uma agenda política que pressupunha, em sua elaboração, a adoção de uma ética ambiental. Esse movimento, sobretudo nas cidades da América do Norte e Europa, surgiu vinculado à noção de sustentabilidade e apoiava-se na noção fenomenológica de que uma relação com a natureza é essencial para a plena realização das potencialidades humanas no planeta (Nesbitt, 2008, p. 74). 
A partir desta primeira aproximação ao conceito, propõe-se discutir suas sucessivas mudanças. Algumas categorias de análise da resiliência, ao se somarem à análise de riscos naturais, tecnológicos, econômicos, sociais e políticos, ganharam novas denominações como resiliência organizacional, espacial, física, funcional, social e urbana - sendo esta última categoria a que mais se presta à análise das transformações decorrentes dos processos de regeneração urbana em centros históricos.

Segundo define Holling (1973, 2001), a resiliência urbana traduz a medida das alterações desencadeadas e toleradas pelas cidades, antes de se reorganizarem integralmente em torno de novas estruturas e processos. Ao aplicar-se o conceito para a leitura do território, é possível mesclar as componentes física e humana, correspondendo a uma rede de infraestruturas e de comunidades, onde os sistemas físicos se compõem de elementos construídos e biofísicos (Gonçalves, 2016; Holling, 2001).

Essa definição está em concordância com Farias (2017) e com o documento preparatório do Habitat III (2015), que afirma que a resiliência urbana é ao mesmo tempo uma aspiração e um método, que serve de base para a definição de um leque de intervenções e investimentos estratégicos em um "sistema urbano", que pode ser entendido através das inter-relações entre escalas (organizacional, espacial, etc.) e riscos (naturais, sociais, políticos e outros).
As consequências sobre a prática se fazem sentir em interpretações às vezes incompatíveis, já que cada campo disciplinar traz para si um significado de resiliência, de modo a adequálo ao seu objeto e às suas correspondentes problemáticas. No Brasil, por exemplo, há distintas abordagens entre a engenharia ambiental e o planejamento urbano e regional (Farias, 2017, p. 5).

Como aponta Farias (2017), para definir a resiliência, é preciso mobilizar noções anteriores, que permitam relacionar todos os termos, porém, nem sempre eles aparecem relacionados entre si. Como exemplo, a seguir, examina-se brevemente as relações entre os conceitos de resiliência, vulnerabilidade e de sustentabilidade.

Para ganhar significado no campo das ciências sociais, as análises sobre resiliência tendem a ser muito próximas das de vulnerabilidade (Barroca, DiNardo e Mboumoua, 2013). No entanto, desde suas origens, há uma diferenciação clara entre os dois termos (Silva, 2014). A resiliência refere-se a uma qualidade, enquanto a vulnerabilidade remete a um estado. A vulnerabilidade é útil para identificar, a posteriori, um estado crítico, enquanto a resiliência seria a parte positiva da vulnerabilidade, sinalizando uma capacidade de ação. Os dois termos, no entanto, estão longe de ser opostos, pois compartilham o pressuposto de uma capacidade de lidar com 
uma situação. É possível, portanto, ser ao mesmo tempo vulnerável e resiliente (Farias, 2017).

A articulação entre resiliência e sustentabilidade também exige esclarecimentos. Segundo Toubin, Lhomme, Diab, Serre e Laganier (2012), a primeira pode ser definida como um ideal urbano a ser alcançado, e a segunda, como a ferramenta para concretizar este ideal.

Como afirma Adger (2003), as «aspirações não focalizadas da sustentabilidade estão incluídas no conceito de resiliência - a capacidade de persistir e adaptar». Porém, sustentabilidade é uma noção altamente antropocêntrica e em parte subjetiva, na qual subjaz um julgamento de valor moral quanto aos objetivos desejáveis, à escolha dos territórios e à escala de tempo. Sendo assim, "a dialética entre sustentabilidade e resiliência também não é uma relação estática" (Farias, 2017) quando articulada pelas práticas de requalificação urbana, por distintas gestões municipais.

\section{0 caso de estudo e a metodologia da pesquisa}

Para o desenvolvimento da pesquisa em curso, a metodologia se apoiou em duas frentes: a revisão bibliográfica e a análise de um caso de estudo. Buscou-se um aprofundamento conceitual por meio da revisão bibliográfica e teórica relativa aos processos de regeneração e resiliência urbana. Uma vez definidos os conceitos e verificadas as possibilidades de leitura que poderiam oferecer para a compreensão dos fenômenos urbanos ocorridos nos últimos vinte anos, e em especial, no centro da cidade de São Paulo, avançou-se para uma pesquisa de campo, exploratória, destinada a caracterizar e analisar um objeto de estudo, a Praça Franklin Delano Roosevelt (Figura 1), mediante o levantamento de dados e análise dos sucessivos projetos implementados, ao longo do tempo, de seus programas de necessidades (planejados e executados) e da verificação da qualidade das propostas apresentadas. As fontes para a discussão deste último aspecto, num primeiro momento, foram os dados levantados junto a órgãos públicos (secretarias municipais e autarquias), os estudos acadêmicos já existentes sobre a praça, as notícias de problemas ocorridos após a conclusão dos projetos e a atuação de grupos ou coletivos formados por moradores, proprietários de pequenos negócios e usuários da área, por meio de blogs e acompanhamento das manifestações organizadas em redes sociais e in loco, na própria praça. Num segundo momento, pretende-se empreender entrevistas com estes mesmos atores/agentes identificados nessa etapa exploratória, para coleta de informações. Após este procedimento, pretende-se realizar o cruzamento das informações destas duas etapas para a síntese final e conclusão da pesquisa. 


\section{A Praça Roosevelt, no centro histórico de São Paulo}

O Centro Histórico de São Paulo (Figura 2) engloba os distritos da Sé e da República, separados pelo Vale do Anhangabaú. O distrito da Sé é chamado de "centro velho", onde se localiza o Pátio do Colégio, sítio de celebração da primeira missa realizada pelos padres Jesuítas em 1554. É também conhecido como "triângulo histórico", formado por três ruas que se cruzam, território onde se realizou o ato fundacional da cidade. Já o distrito da República, localizado do lado oposto do Vale onde se localiza a Praça Roosevelt, objeto deste estudo - consolidou-se posteriormente, a partir do século XIX e início do XX, como o "centro novo”, com a localização das funções centrais já voltadas ao comércio demandado pela fixação de residência das elites paulistas, bem como de construções modernas. A partir dos anos 30 do século passado, esse perímetro, constituído pelos dois lados do Vale do Anhangabaú, foi delimitado por um sistema de avenidas perimetrais, implantadas a partir de proposta do Plano de Avenidas do Engenheiro Francisco Prestes Maia.
FIGURA 1. A PRAÇA ROOSEVELT NA ATUALIDADE.

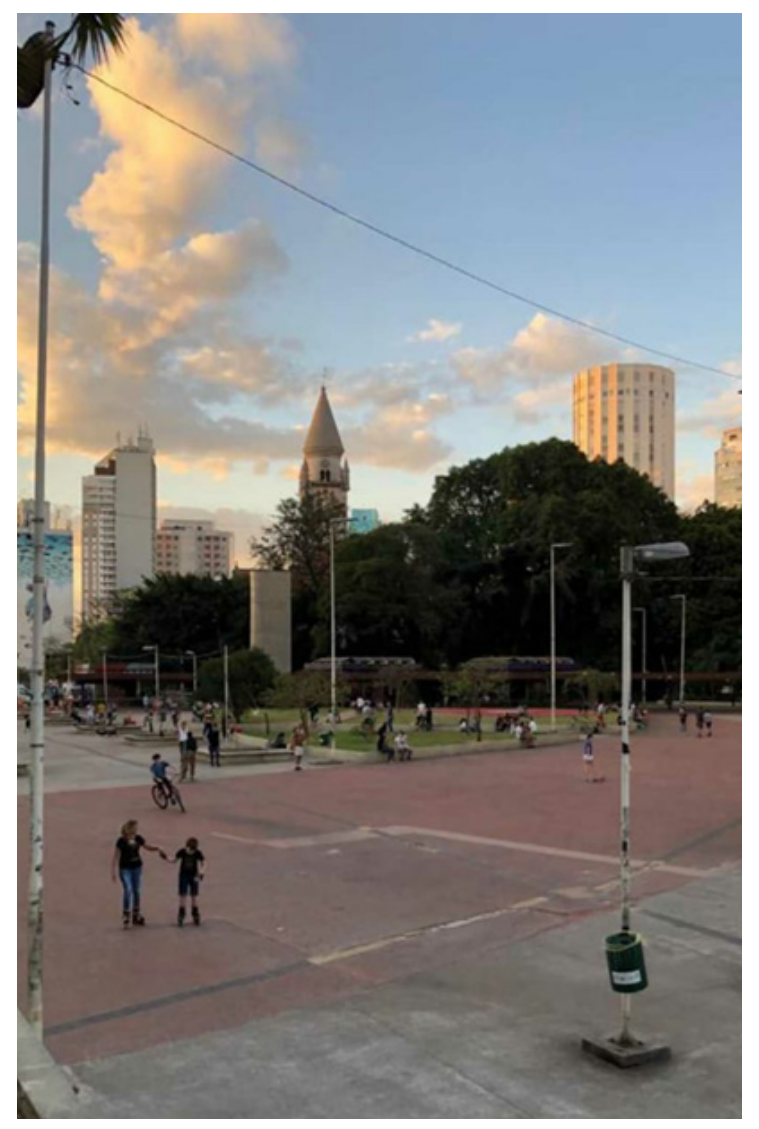

Fonte: Elaboração própria, 2020. 
Inserida neste contexto e com área de cerca de $18.000 \mathrm{~m}^{2}$, a Praça Roosevelt é limitada pelas ruas da Consolação, Martinho Prado, Augusta e Guimarães Rosa, possuindo atualmente em seu entorno uma grande diversidade de usos (teatros, bares e comércios de rua, edifícios residenciais, hotéis, edifícios corporativos e edifícios institucionais - como Escolas, Universidades, Igrejas), além de funcionar como cobertura de parte do canal viário estruturante que liga a zona oeste à zona leste da cidade através do centro. Ela é resultado de uma área remanescente de chácaras da família Martinho e Veridiana Prado e foi entregue ao poder público na década de 1930, no intuito de solucionar problemas sanitários existentes no local.

A praça, que se formou ao redor da Igreja da Consolação, manteve a denominação Praça da Consolação até 1950, quando se decidiu alterála para homenagear o ex-presidente americano Franklin Delano Roosevelt. Entre as décadas de 1950 e 1960, a praça se transformou numa grande área asfaltada, vazia, servindo de área de estacionamento em meio aos prédios residenciais, lojas, bares, restaurantes e teatros que se instalaram em seu entorno.

A ligação do eixo Leste-Oeste da cidade, com a construção de uma via expressa que cruzava o centro histórico, implantada na década de 1970, mudou radicalmente a configuração do local. As obras viárias rasgaram a praça existente, dando lugar a um novo projeto que foi implantado no sentido de servir como uma "tampa" para o túnel construído sob a praça (Calliari, 2012).

Projetada em 1968 e inaugurada em 1970 por ocasião do $416^{\circ}$ aniversário da capital paulista, era constituída por um conjunto arquitetônico de concreto em cinco pavimentos, e repercutiu na capital o contexto marcado pelo chamado "milagre econômico brasileiro" e pelos reflexos do processo de metropolização paulistano. Neste sentido, ela representa o pragmatismo da modernidade e a busca pela eficiência (estética, funcional e programática) de uma época, tendo como importantes referências os processos de renovação das áreas centrais de outros países, com a implantação de megaestruturas multifuncionais, ou o modelo de centralidades das "New Towns" inglesas do pós-guerra ("Praça Franklin Roosevelt e entorno", 2009, p. 6).

Assim como ocorreu em outras áreas do centro histórico no mesmo período, sua degradação física se acentuou entre as décadas de 1980 e 90. Neste contexto, de acordo com Calliari (2012), a praça enfrentou problemas de violência, sujeira, poluição visual e obstrução do trânsito para pedestres, iniciando um processo de obsolescência a partir do fechamento de algumas lojas, bares e restaurantes de seu entorno. As discussões sobre uma possível reforma da praça se iniciaram em 2004, quando a cidade conseguiu um grande financiamento do BID (Banco Interamericano de Desenvolvimento) para o programa PROCENTRO, destinado a promover melhorias no ambiente urbano da área central. 
FIGURA 2. O PERÍMETRO DO CENTRO HISTÓRICO DE SÃO PAULO CONTORNADO EM ROXO E O TRIÂNGULO HISTÓRICO, PONTILHADO EM AMARELO.

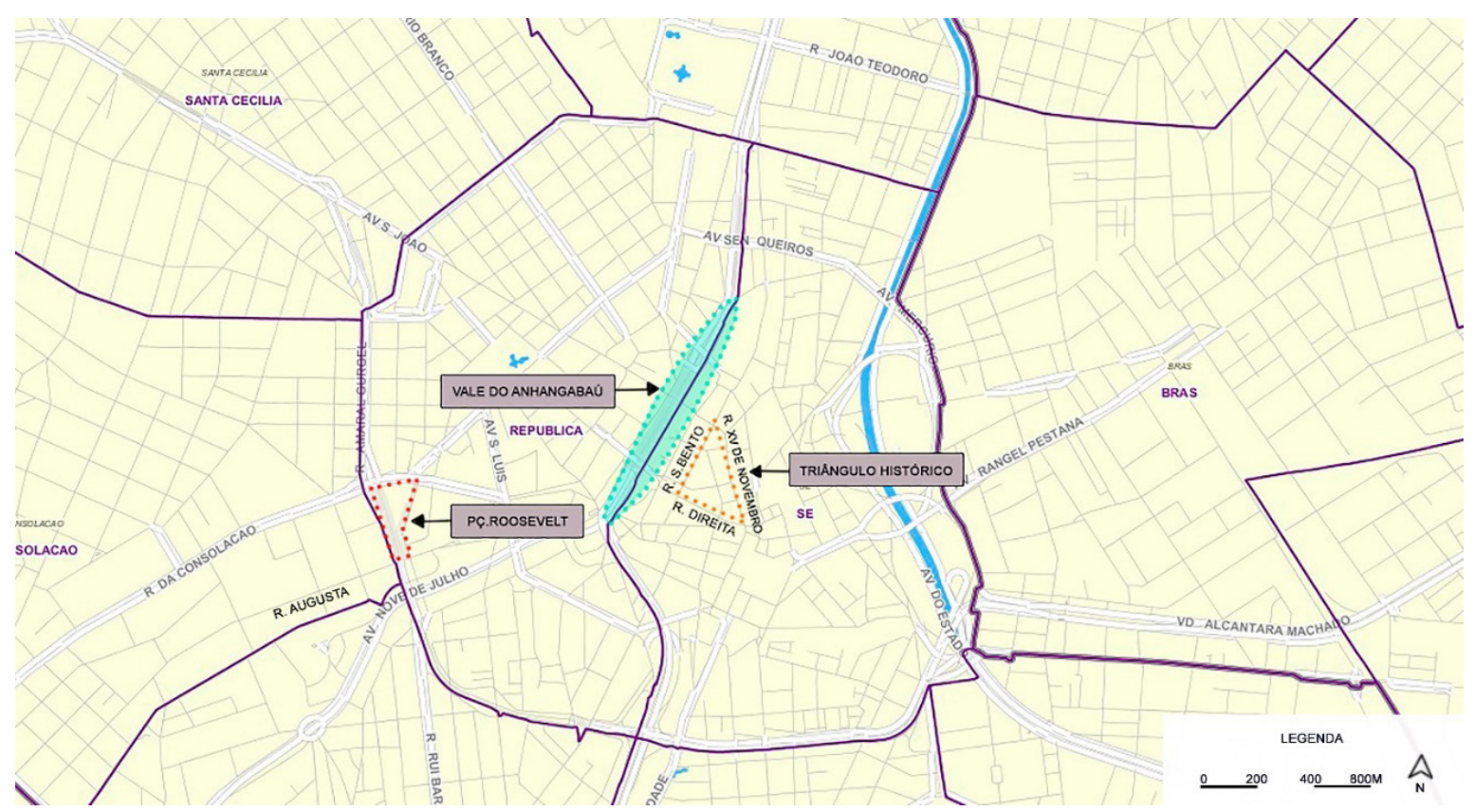

Fonte: Elaboração própria, 2020

A estigmatização associada à falta de manutenção e às dificuldades de gestão resultaram, nos anos que antecederam a recente intervenção, em uma ocupação da Praça de outra natureza. Caracterizada pela presença de moradores de rua, as discussões em torno das possibilidades de sua transformação se acentuaram, reafirmando uma perspectiva socialmente saneadora e embelezadora. Neste momento, começaram a se configurar as condições propícias a uma intervenção de regeneração urbana nos moldes já discutidos, onde obsolescência, vacância/rotatividade dos usos e ausência de manutenção física tornamse problemas a serem solucionados a partir de financiamentos privados externos, em parceria com o poder público local. 
FIGURA 3. CONCEPÇÃO DO CONJUNTO EM 1970 E SEUS EQUIPAMENTOS.

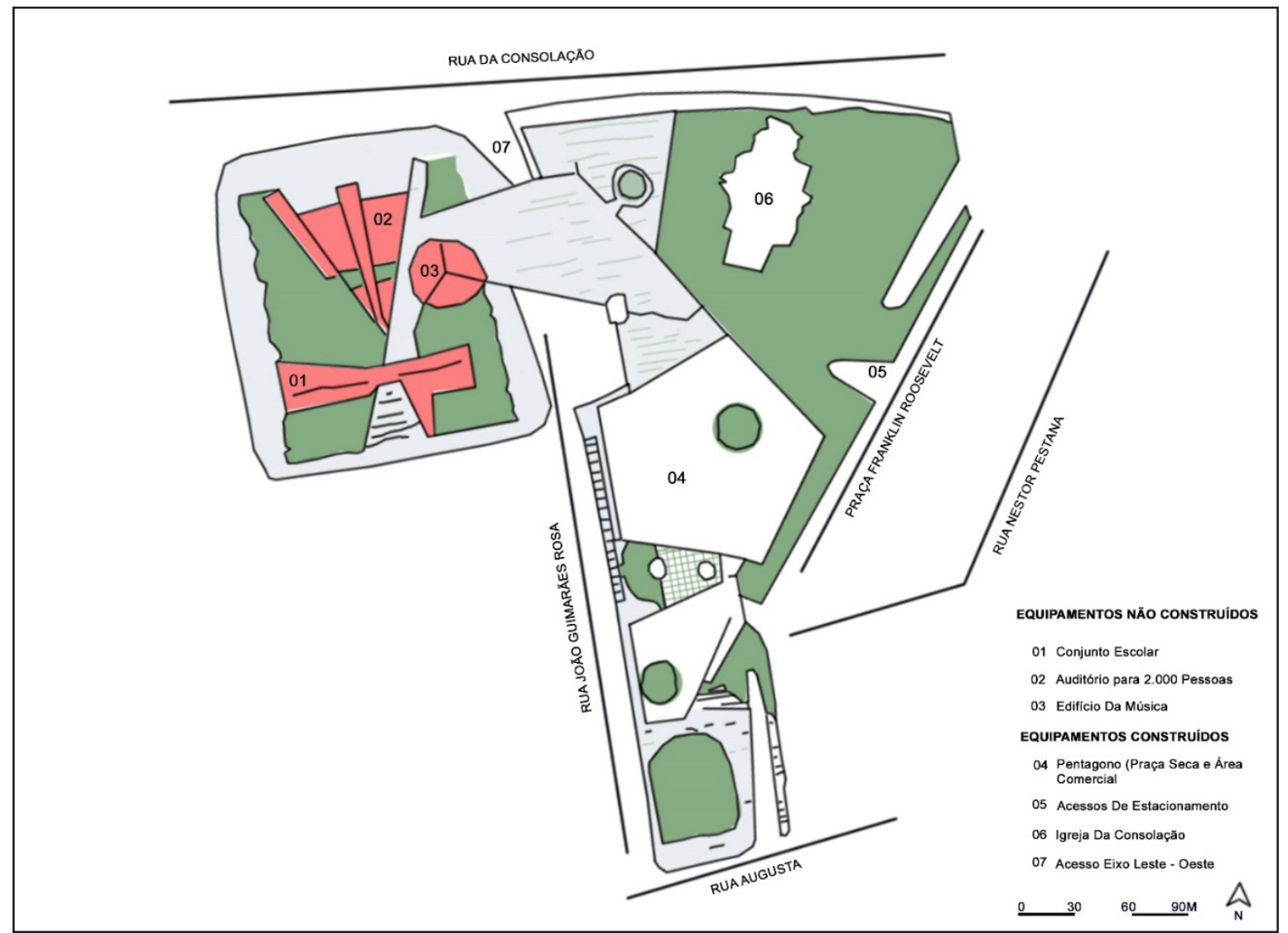

Fonte: Elaborado pelos autores (2020), a partir de Cardozo e Antunes Netto (1970, p. 12). 


\section{As intervenções urbanas recentes na Praça Roosevelt (2010-2012)}

A intervenções recentes na Praça Roosevelt, previstas no projeto executivo elaborado em 2008, pelo escritório Figueiredo Ferraz, e revisado em 2010, quando se iniciaram as obras pelo escritório Borelli \& Merigo - ambos contratados pela empresa pública SP Urbanismo -, promoveram alterações de renovação substanciais. $O$ projeto definiu a implantação de um novo paisagismo, de estacionamentos públicos, quiosques, posto policial, cachorródromo, teatro de arena, além da requalificação de calçadas e recuperação e/ou restauro de alguns dos edifícios de seu entorno. Contudo, por ter sido reinaugurada às pressas pelo então prefeito Gilberto Kassab, em 29 de setembro de 2012, os elementos previstos no projeto da praça não foram totalmente entregues à população. $O$ teatro de arena não foi construído, o cachorródromo foi substituído por um playground para crianças e as pistas de skate - não previstas no projeto original somente foram entregues em novembro de 2014 (Yamashita, 2013, p. 177).

O espaço público e as estratégias envolvidas na renovação da Roosevelt repercutem um modelo de intervenção que está diretamente associado ao conjunto de práticas e políticas vinculadas à regeneração urbana. Revelam ainda um novo protagonismo dos governos locais que buscam políticas comuns, difundidas internacionalmente, para lidar com os problemas que se manifestam em seus territórios, buscando intervir nos seus centros antigos para recuperar qualidades ou funções que estariam sendo perdidas.

As intervenções recentes na Roosevelt (20102012) reforçam o entendimento dos atributos presentes nos processos de regeneração urbana apontados por Mendes (2013): abrangência, integração, apoio em parcerias, estratégia, flexibilidade e resiliência. Assim, para evidenciar a incidência desse processo na Praça, utiliza-se como recurso a leitura de alguns destes tópicos.

O processo de regeneração urbana possui como uma de suas principais características a abrangência. Busca não apenas resolver, na mesma intervenção, problemas morfológicos, econômicos, de caráter social e ambiental, mas, sobretudo, definir de maneira sistêmica os procedimentos e medidas de intervenção que afetem de forma positiva todos os setores da área urbana considerada. Em decorrência desta primeira, surge uma outra característica: a integração. Nessa, o desafio é desenvolver ações de modo que a área urbana, alvo de intervenção, seja sempre considerada de forma integrada, seja pela integração dos seus vários espaços com o território que a envolve, seja pelo estabelecimento de uma gestão capaz de gerir financiamentos e conciliar políticas 
de diferentes esferas públicas na elaboração e implementação do processo.

Ambas as características, abrangência e integração, estão presentes nas intervenções empreendidas na Roosevelt. Materializamse através da Operação Urbana Centro (OU Centro) que apresenta uma série de ações concertadas entre diferentes intervenções pontuais no perímetro do centro histórico. As Operações Urbanas são instrumentos de intervenção pública, reguladas pelo Plano Diretor e aprovadas mediante lei municipal, que estabelecem regras urbanísticas específicas $\mathrm{e}$ incentivos ao adensamento populacional e construtivo para uma determinada área da cidade, com perímetro previamente definido. Têm por objetivo alcançar metas de qualificação para os territórios que abrangem, por meio de um conjunto de diretrizes urbanísticas, como estabelece o Estatuto da Cidade (Lei Federal 10.257 de 2001).

A Ou Centro (Figura 4), foi criada com o objetivo de promover a melhoria e a revalorização da área central, para atrair investimentos imobiliários, turísticos e culturais e reverter seu processo de deterioração. Abrange as regiões dos chamados Centro Velho e Centro Novo, bem como parte de bairros históricos como Glicério, Brás, Bexiga, Vila Buarque e Santa Ifigênia.

Esta operação estabeleceu incentivos, mediante contrapartida financeira para a produção de novas edificações, regularização de imóveis, reconstrução e reforma das existentes para sua adequação a novos usos, e estabeleceu condições especiais para a transferência de potencial construtivo de imóveis de interesse histórico.

Inserida neste contexto, a reinauguração da Praça Roosevelt, em 2012, apresenta os melhoramentos que foram surgindo em resposta às diferentes agendas voltadas ao desenvolvimento urbano da área central, já preconizados na OU Centro - visando promover nova vitalidade e qualidades na Praça e nos diversos espaços públicos associados a ela - em função do crescimento da metrópole, da mudança de usos e da concentração de investimentos, implementados pelas diferentes gestões públicas municipais, ao longo dos anos.

As ações desenhadas no projeto inicial, estruturado em duas etapas e apresentado pela Empresa Municipal de Urbanismo de São Paulo [EMURB] em 2009, também ilustram as características da abrangência e integração.

$\mathrm{Na}$ primeira etapa, o projeto consistiu em ações de renovação da praça, através de: demolições de acessos, muretas e lajes de cobertura, recuperação do estacionamento existente, implantação de novas edificações e o desenvolvimento de um novo projeto paisagístico. $\mathrm{Na}$ segunda etapa, o projeto priorizou o entorno da praça, através de uma abordagem em larga escala vinculando sua requalificação às demais ações em 
desenvolvimento na área central, através do restauro de edifícios, do alargamento de passeios públicos, instalação de novas infraestruturas, da abertura de visuais, além das estratégias voltadas aos cortiços buscando dar condições de habitabilidade a essas moradias.

Além disso, a EMURB, atual SP Urbanismo, apresentou, junto ao projeto, uma proposta de gestão compartilhada - outra característica dos processos envolvidos na regeneração urbana - do espaço da área envoltória para além da praça. A Secretaria Municipal de Habitação, a Secretaria do Verde e do Meio Ambiente e as Subprefeituras da Sé e da Mooca, se articularam de modo a orientar o destino dos recursos financeiros obtidos através de financiamento, bem como definiram as responsabilidades pela zeladoria e por apresentar soluções - dentro de cada uma de suas respectivas áreas de atuação aos problemas identificados na área (abandono, moradias precárias, vacância, entre outros). Essas ações correspondem ao segundo aspecto da integração preconizado no modelo.

Outra característica, o apoio a partir de parcerias, se preocupa com as dinâmicas organizacionais e institucionais de gestão da mudança urbana, mobilizando esforços conjuntos, seja pela organização de uma base coletiva para a tomada de decisões, seja pela crescente exigência da participação popular na definição de soluções em nível local; pelo apoio dado pelas parcerias, no sentido de permitirem uma maior coordenação e complementaridade entre diferentes competências de diferentes agentes, ultrapassando possíveis barreiras institucionais; ou mesmo pela compreensão de que os processos de regeneração urbana quase sempre envolvem grandes investimentos que dificilmente poderiam ser suportados por uma só entidade (Mendes, 2013).

Ao analisar a proposta de gestão compartilhada para a Roosevelt, verifica-se a abertura da participação do setor privado através de ações a serem realizadas em conjunto com entidades e empresas sediadas ou vinculadas ao centro histórico, apoiadas por órgãos da Prefeitura (Prefeitura Municipal de São Paulo, 2004). Como evidência disso, temos a participação da Associação Viva o Centro durante o processo, repercutindo principalmente os interesses econômicos da elite empresarial local, tanto na apresentação das suas necessidades quanto pelas críticas ao projeto apresentadas pela EMURB. No caso específico desta associação, a estratégia de gestão compartilhada se dá através da oferta de apoio logístico (informações, material gráfico, mapas da microrregião em que atua, apoio técnico para organização de reuniões etc.), de informações sobre procedimentos para encaminhamento de demandas e sugestões referentes à prestação de serviços públicos, da redação de circulares convocando reuniões ou divulgando instruções e da consultoria técnica em geral e organização de palestras junto aos órgãos públicos. Por outro lado, é 


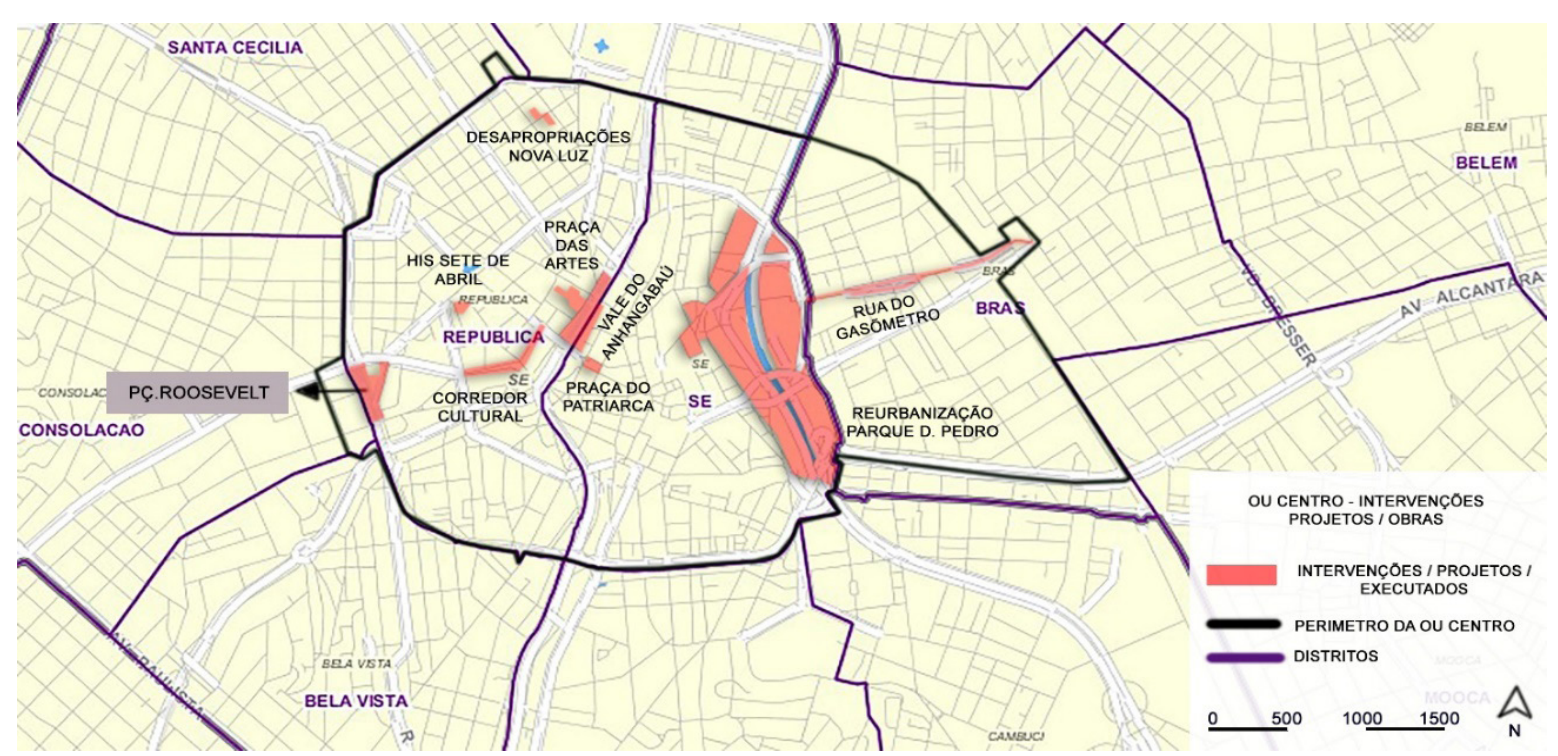

Fonte: Elaborado pelos autores (2020) a partir de "Ou centro", 2017, p. 97.

importante ressaltar que tal proposta de gestão compartilhada não considerou a participação da população local, tanto dos moradores do entorno quanto dos diferentes usuários da praça - em sua maioria constituída por sem tetos e ambulantes - o que acabou gerando uma série de conflitos e tensões sociais em seu território conforme detalha-se mais adiante.

O caráter estratégico resulta da necessidade de alteração ou reestruturação funcional de uma determinada área de intervenção e, portanto, torna crucial o estabelecimento de ações a médio prazo, feitas em função dos resultados desejados e de objetivos claros previamente traçados. Neste caso, visando a renovação tanto da Praça quanto de seu entorno imediato, a reestruturação passou não apenas pelo redesenho do seu espaço físico como também serviu para reforçar as diretrizes do Plano Diretor Municipal, elaborado em 2005. Este, classificava a área onde se localiza a Praça Roosevelt como uma das "Áreas de Intervenção Urbana" - porções do território de especial 


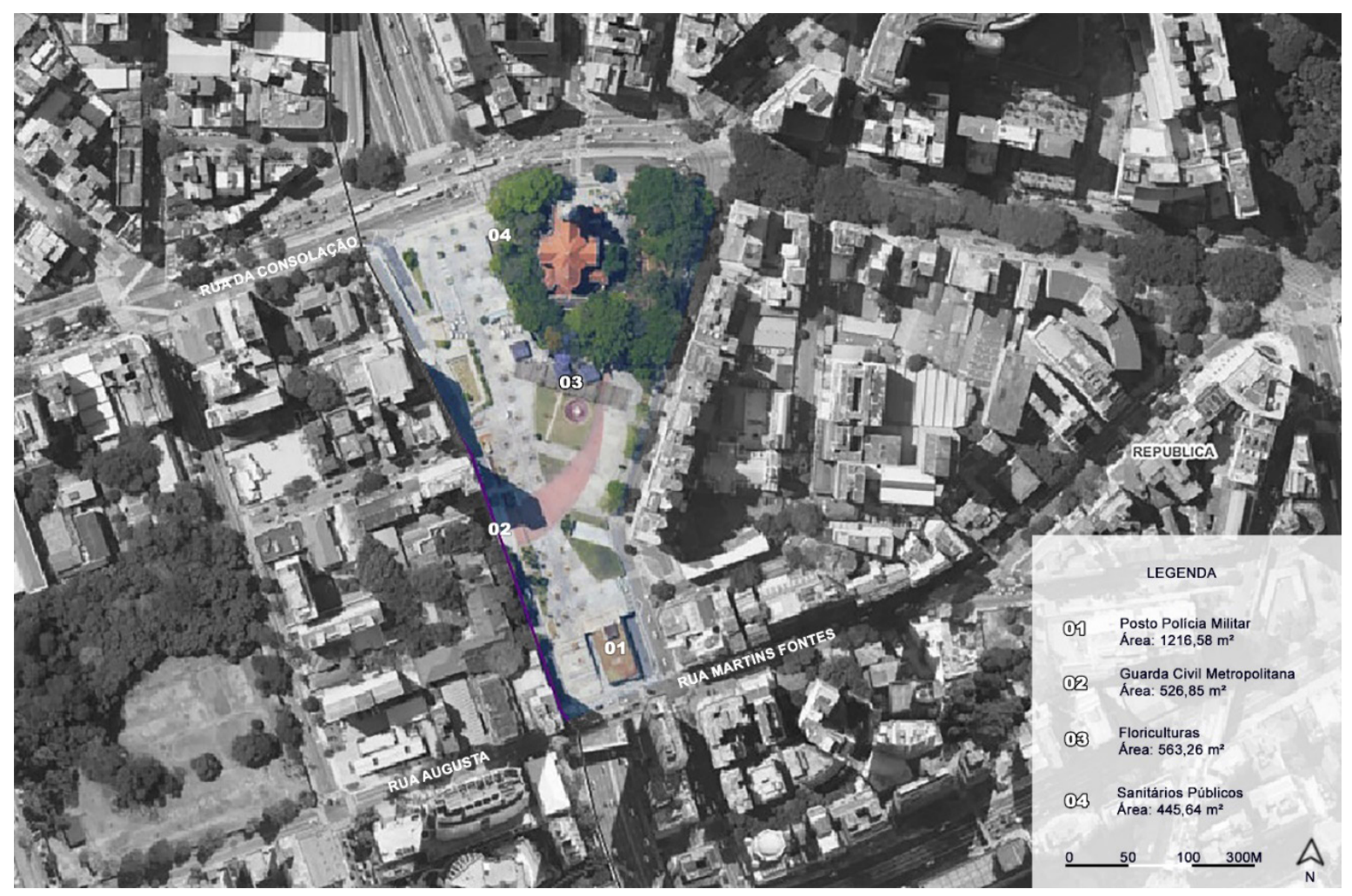

Fonte: Elaborado pelos autores, 2020.

interesse para o desenvolvimento urbano, objeto de projetos urbanísticos específicos, nos quais podem ser aplicados os instrumentos de intervenção previstos no Estatuto da Cidade - reforçando ainda a dinâmica de uso misto (comércio, serviços e habitação) - pretendida para grande parte da área central. O Estatuto da Cidade - Lei n ${ }^{\circ} 10.257$ de 10 de julho de 2001 - foi criado para regulamentar os artigos 182 e 183 da Constituição Federal 
FIGURA 6. PRINCIPAIS AÇÕES DE INTERVENÇÃO NO ENTORNO DA PRAÇA.

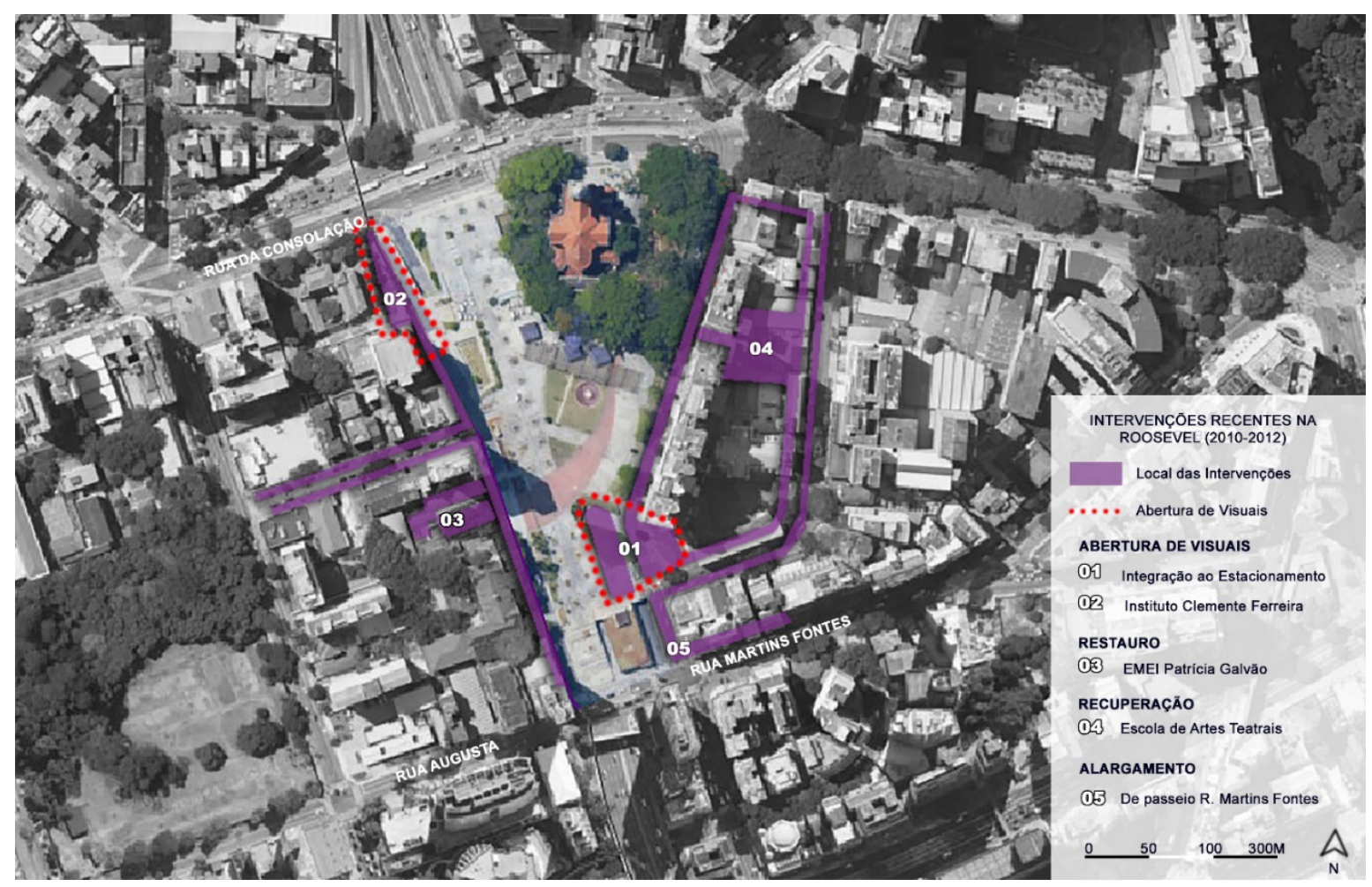

Fonte: Elaborado pelos autores, 2020.

Brasileira de 1988, que conformam o capítulo relativo à Política Urbana. Reúne importantes instrumentos urbanísticos, tributários e jurídicos que podem garantir efetividade ao Plano Diretor Municipal, responsável pelo estabelecimento da política urbana na esfera municipal e pelo pleno desenvolvimento das funções sociais da cidade e da propriedade urbana. Entre seus instrumentos, estão alguns que implicam diretamente ações em centros ou áreas consolidadas, como a transferência do direito de construir, o direito de preempção, a outorga onerosa e o direito de superfície. O instrumento do Estatuto que foi mais implementado durante o período analisado foi a Operação Urbana, pois permite associar vários dispositivos definidos 
no Estatuto em uma mesma área (para mais informações, consultar "Operações Urbanas", s. f.).

Por fim, a flexibilidade decorre da própria característica estratégica do processo e da necessidade de conferir sustentabilidade ao mesmo. As regras definidas para o alcance dos objetivos estratégicos devem prever mecanismos de readaptação que se apresentarão durante a implementação, visando corrigir possíveis mudanças ocorridas no cenário previsto em função do diagnóstico inicial. No caso de São Paulo, a flexibilidade pode ser atribuída ao fato de que as diferentes ações de intervenção foram orientadas, adaptadas ou atualizadas através do próprio Plano Diretor Estratégico Municipal, que deve passar por uma revisão a cada dez anos. Por outro lado, também se vincula à ideia de resiliência, como se verá a seguir, ou seja, à capacidade de determinado grupo de adaptarse positivamente às possíveis mudanças do cenário previamente estabelecido.

\section{A Praça Roosevelt resiliente: discussão e resultados parciais}

A reflexão sobre os impactos deste modelo de intervenção urbana nos territórios locais, em decorrência das disputas e conflitos sociais, é o último aspecto do recorte de análise proposto neste artigo. O centro histórico de São Paulo, de forma geral, constitui-se historicamente num território de disputas, consubstanciadas, em grande parte, pelas próprias práticas de requalificação urbana que ciclicamente foram implementadas, por distintas gestões municipais, em especial, a partir do final dos anos 1990 (Schicchi e Benfatti, 2004).

Além disso, há inúmeras forças que atuam sobre o território, que se expressam através dos interesses de grupos econômicos e sociais específicos -como a Associação Viva o Centro, ou como o próprio mercado imobiliário, de um lado, e os movimentos populares de moradia, como o Movimento de Moradia o Centro (MMC), a Frente de Luta por Moradia (FLM), o Fórum de Cortiços e Sem Tetos de São Paulo, o Movimento Unificado dos Trabalhadores Ambulantes da Cidade de São Paulo, etc., de outro- que atuam permanentemente sobre as políticas propostas para a área e protagonizam tais disputas (Maricato, 1996).

A partir da experiência da Praça Roosevelt, em sua dimensão urbana, cultural e social, foi possível constatar que as práticas sociais resultantes das intervenções urbanas, ao ressignificarem suas construções e lugares de convívio, revelaram conflitos intrínsecos à produção do espaço urbano na cidade de São Paulo, de forma mais geral.

De modo a exemplificar como se detectou o fenômeno de resiliência urbana, ou seja, a leitura dos fenômenos de deslocamentos e/ou adaptabilidades, apontam-se as particularidades 
dos processos decorrentes das intervenções realizadas na praça, em especial, as que interrelacionam efeitos em nível local e global.

O projeto, apresentado inicialmente pela EMURB, em setembro de 2009, citado anteriormente, não deixa dúvidas de que o espaço público foi concebido para ser visto, não para ser apropriado. O campo visual é privilegiado, em consonância com um urbanismo que promove a cidade para o consumo cultural, através de políticas de criação de imagem, com intuito de transformar a cidade em um grande empreendimento, ou num produto negociável.

As ações de intervenção urbana da área central, assim como o ocorrido no caso da Praça Roosevelt visavam, portanto, não somente atender às exigências dos empresários e entidades locais - representados durante o processo pela Associação Viva o Centro -, como também os interesses econômicos do próprio Estado. Neste sentido há que se destacar o debate realizado entre os diferentes agentes atuantes no projeto e os representantes da sociedade civil, que selou a condição atual desse espaço público.

Em março de 2009, a EMURB apresentou um documento que refletia as demandas da população local - ou de parte delas - para o projeto de intervenção, em resposta ao plano inicial proposto pela Prefeitura. Neste documento, foi apresentado um diagnóstico, elaborado a partir de dados enviados pela Associação Viva o Centro, indicando pontos favoráveis e contrários ao projeto, informações sobre o andamento das obras, orçamentos e ações para o entorno.

Deste modo, junto às intervenções físicas $e$ sociais na Praça e seu entorno, também foi desenvolvida uma nova proposta de gestão que possibilitaria a participação do setor privado, sobretudo em razão dos novos usos previstos ("Praça Franklin Roosevelt e entorno", 2009).

A Praça Roosevelt constitui um espaço caracterizado pela transitoriedade, diversidade, espontaneidade e fluidez próprios de sua natureza pública. A diversidade presente na sua ocupação revela a existência de inúmeras categorias sociais que ganham expressão concreta no espaço, ou seja, a presença de diferentes territórios sociais que se cruzam no território da praça: a comunidade LGBT, os estudantes (de ensino primário, secundário e universitários), os skatistas, os moradores locais (moradias formais e informais), os artistas de teatro, o bloco carnavalesco do Baixo Augusta, a forte presença de população em situação de rua, os comerciantes, as instituições públicas (educacionais, de cultura e de segurança pública), o comércio ilegal/informal, os territórios de prostituição, etc. 
Estes moradores e usuários sempre estiveram presentes na praça, em alguns casos, mesmo quando o abandono e a evasão de usos e de populações reforçavam o cenário de degradação do seu espaço. Neste sentido, houve uma convergência de interesses $e$ necessidades dos estabelecimentos teatrais em relação à importância da implementação de ações urbanísticas mais elaboradas, para além dos simples reparos e manutenções, vistos a partir dos anos 2000 (Yamashita, 2013). Nesse período foi possível reconhecer também um maior protagonismo da Companhia de Teatro "Os Satyros" e o reflorescimento das atividades teatrais na Roosevelt, onde a visibilidade adquirida pelo grupo teve um papel importante no processo de transformação da praça.

"É conhecida a importância dos Satyros e outros grupos teatrais no processo de urbanização do entorno da Praça Roosevelt. Nos Satyros, sempre foi clara a ideia de que o fenômeno teatral não se restringia apenas ao que se passava na sala de espetáculo (...) toda a dinâmica urbanística da Roosevelt tornouse parte fundamental da própria estética do grupo" (Vasquez, 2015).

A produção dos Satyros está amparada por concepções teatrais que se centralizam em questões do universo urbano e contribuem para tornar públicos os problemas enfrentados no centro. Sob outro aspecto, as ocupações deste grupo teatral trouxeram novos usos para áreas abandonadas e degradadas da praça, estimulando a vinda de novo público e grupos sociais. Assim, os Satyros se tornaram portavozes da urbanidade e da convivência entre grupos diferentes no espaço público, resultando num certo enobrecimento, construído através das ações culturais na praça e seu entorno.

Outros exemplos de resiliência e permanência de usos da praça se deram através da apropriação feita por grupos de skatistas, que já usavam a praça na época em que esta estava "abandonada" e que ainda hoje a utilizam para a realização de manobras esportivas e a presença de grupos musicais que realizam semanalmente duelos de rap e Hip-Hop, imprimindo visibilidade aos "ritmos" da periferia no centro urbano da metrópole paulistana, mesmo que, em ambos os casos, o projeto inicialmente realizado pela EMURB não tenha contemplado um espaço específico para a realização destas atividades (Levenstein, 2012).

Outro aspecto importante, decorrente das intervenções, diz respeito aos deslocamentos de usos e populações, gerados em função do aumento do custo da moradia, do comércio e serviços, devido à intensificação da valorização imobiliária no centro histórico, onde ocorreu o fenômeno da gentrificação, processo que também auxilia a compreensão da resiliência no território da Roosevelt.

O levantamento das áreas envoltórias à praça evidenciou que os novos empreendimentos se localizam na Rua Augusta, principal rua nas 
proximidades da Praça, que teve entre 1985 e 2013 a maior concentração de negócios imobiliários dentro do perímetro do Centro e que já possuía uma tradição de ocupação por atividades noturnas desde os anos 1960. Em paralelo, a concentração de casas noturnas provocou uma mudança de público, atraído pela característica boêmia da região, reforçada pelas atividades culturais dos grupos de teatros ali instalados.

Segundo Yamashita (2013), ocorreu uma valorização dos imóveis em seu entorno em mais de $600 \%$ em oito anos. A autora apresenta importantes relatos sobre essa valorização.

"André Mendes (morador há mais de dez anos) informou que adquiriu o seu imóvel (de aproximadamente $55 \mathrm{~m}^{2}$ ) por quarenta e cinco mil reais e hoje é possível vendê-lo por mais de duzentos mil (350\%). O próprio diretor do grupo teatral Satyros, Ivam Cabral, disse que havia adquirido um imóvel em 2000 por vinte e quatro mil reais e que seria possível revendêlo (em 2011) por duzentos mil (730\%)" (Yamashita, 2013, p. 179).

Dados recentes revelaram que "o valor médio do metro quadrado no Centro passou de R $\$ 6.399$ em 2010 para $R \$ 9.762$ na média, entre janeiro e setembro de 2019, segundo dados do Secovi-SP (sindicato do setor imobiliário) — uma alta de 52\%" (Lacerda, 2019). A valorização dos imóveis pode ser lida como um dos indicadores de que os processos de gentrificação ainda se mantém presentes, tanto na praça quanto em seu entorno.
Como consequência, houve um aumento do custo de vida e a intensificação da especulação imobiliária, processos que, juntos, tornaram-se motor da expansão econômica da cidade, de forma mais geral, sendo a área central o lugar estratégico desta nova lógica urbana (Harvey, 1992).

Também se identificaram grupos populares a favor e contra o projeto atual, sobretudo em função de seu uso. De acordo com o Jornal Folha de São Paulo (Miranda, 2012), que ouviu frequentadores e moradores da envolvente à praça, há os que "aprovaram a nova praça mas parte diz se preocupar com a manutenção do local (...) e deve haver regras para os skatistas e mais cercamento da área". Por outro lado, ameaçados com a proximidade do posto policial, os esportistas se defendem: "a gente sempre andou de skate aqui, mesmo quando a praça estava abandonada; e agora que ela está em excelentes condições a gente não pode usar?" (Miranda, 2012).

Esse conflito entre moradores e usuários foi um dos fatores que motivou a elaboração de propostas para a modificação do atual projeto pleiteado pela "Ação Local Roosevelt", que propunham o fechamento com grades no perímetro da praça, de forma a inibir a presença de skatistas que se apropriam constantemente

6 A Ação Local Roosevelt é uma das entidades locais - as Ações Locais - do programa de organização da comunidade do Centro, criado pela Associação Viva o Centro. 
do espaço (Yamashita, 2013, p. 177). Essa mesma Ação Local é responsável por acionar a guarda civil para realizar ações de intimidação e repressão aos skatistas da praça.

\section{Conclusões}

A partir da descrição das intervenções e práticas observadas na praça e seu entorno, foi possível o entendimento das características do modelo da regeneração urbana, às quais se seguiram as de resiliência urbana.

A Praça Roosevelt, localizada no coração da metrópole paulistana, é parte importante da própria história da formação da cidade de São Paulo e reflete planos e projetos que foram implementados em tempos distintos, como resposta às diferentes agendas voltadas ao desenvolvimento urbano no centro. Não obstante, revelou a existência de diversos territórios sociais que se sobrepõem ao seu território físico. Este reconhecimento da Roosevelt enquanto cenário que mobiliza novas e velhas contradições, permitiu a formação de um quadro de questões sobre os conceitos iniciais abordados e seus possíveis desdobramentos nas formas de intervenção e ressignificação de espaços públicos da cidade, na medida em que a leitura da Praça Roosevelt pode ser considerada emblemática para a compreensão dos processos em curso na área central da cidade de São Paulo.
Neste sentido, o espaço não é apenas um receptáculo da história, mas condição de sua realização, através das formas urbanas e práticas sociais que ali se materializaram de forma real e concreta. A revisão da bibliografia possibilitou a definição de uma matriz teórica, adotada para a leitura da resiliência diante dos processos de transformação decorrentes das intervenções no espaço urbano da Praça Roosevelt. Ao analisar e compreender o impacto físico e social desses fenômenos e processos, no âmbito das políticas para intervenção em espaços públicos locais, conclui-se que o resultado destas experiências foi bastante diferente e diversificado, do início das intervenções até o pleno funcionamento dos espaços, conforme foi possível constatar no período entre as primeiras intervenções, nos anos 1970, e as mais recentes, nos anos 2010.

A maior parte das características atribuídas à Regeneração Urbana, o caráter estratégico e abrangente, a ação integrada, a geração de mudanças permanentes e a flexibilidade para incorporar o imprevisível, foram constatadas no projeto e nas propostas específicas para a Praça Roosevelt. Porém, quando se analisou in loco a situação de convívio entre atores e agentes distintos no espaço público, após a implantação do último projeto, revelouse que a dimensão das questões vai além do controle do uso e manutenção dos espaços. Trata-se do reconhecimento da existência de diferentes escalas de disputa nas esferas econômica, social, cultural e política, de 


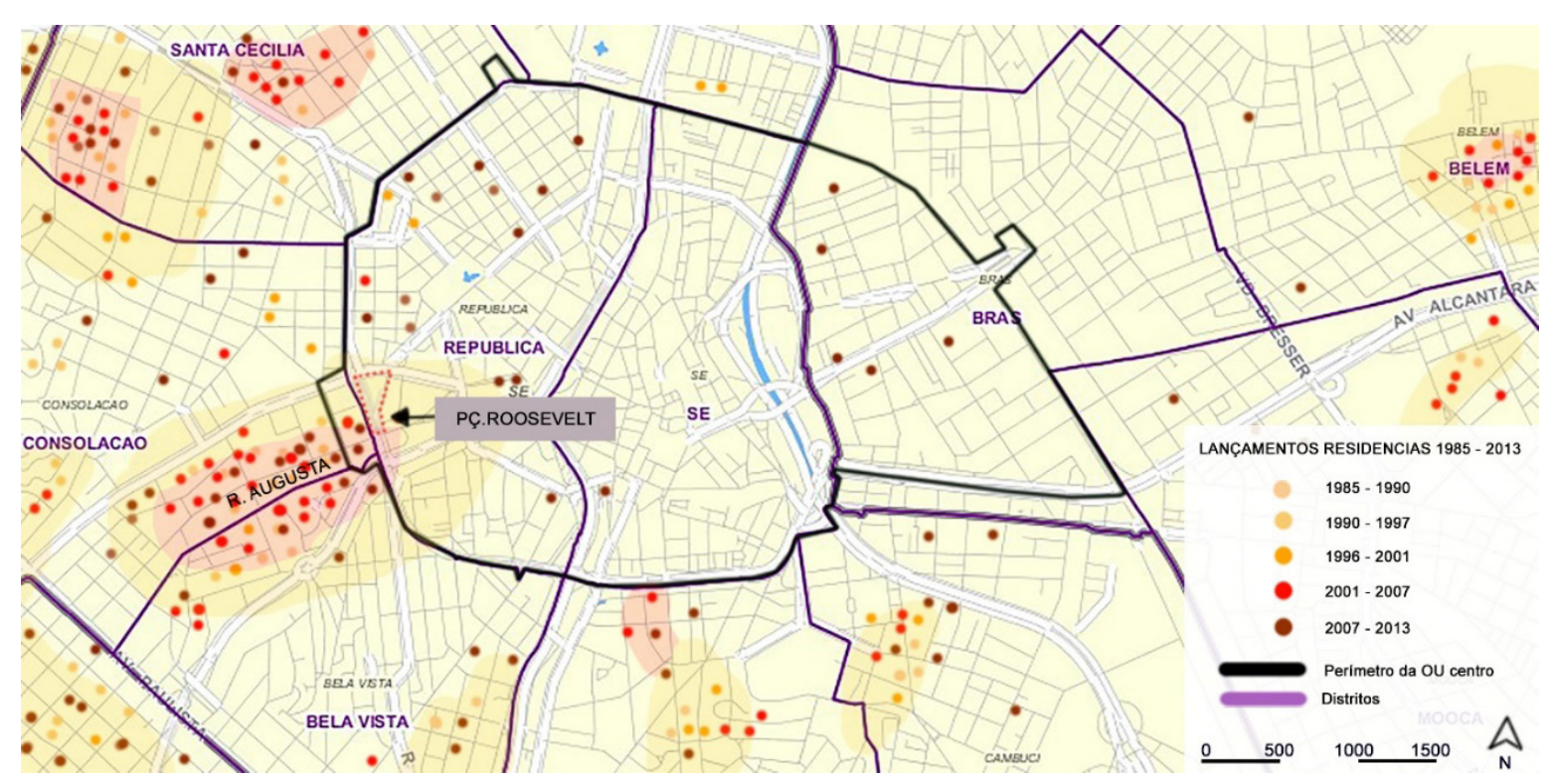

Fonte: Elaborado pelos autores (2020), a partir de "Ou centro", 2017, p. 86.

forma que, ao se equacionar um conflito numa determinada esfera, os efeitos podem ser mais ou menos positivos em outra. No âmbito da intervenção local, em um único território, os empreendedores e proprietários imobiliários podem lucrar com a retirada de usuários indesejados. Porém, muitos destes usuários também garantem a presença de atividades ininterruptas na praça e no entorno e, portanto, as condições de segurança cotidiana, uma das premissas contemporâneas das intervenções de regeneração, e uma das principais diretrizes preconizadas para toda a cidade no atual Plano Diretor Estratégico.

A ausência de uma sincronia entre as ações de regeneração no centro da cidade, que proporcione uma equiparação da qualidade de seus vários setores, faz com que a ação pontual em um espaço produza uma exacerbação dos efeitos positivos e negativos, no período 
FIGURA 8. A PRACA ROOSEVELT E SEU USO COTIDIANO NA ATUALIDADE.

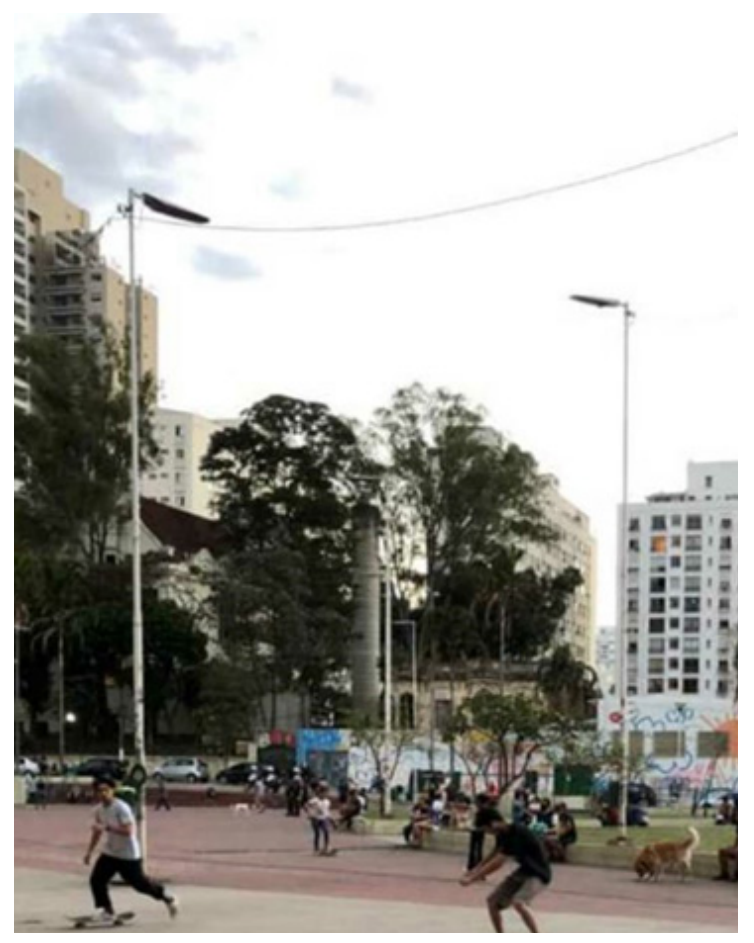

Fonte: Elaboração própria, 2020

imediato de início de uso do espaço, pelo aspecto de novidade e pela grande demanda por espaços públicos de convívio, num centro de metrópole, como é São Paulo. Essa é uma diferença importante, em relação a experiências pioneiras como a de Barcelona, que evidencia a ausência de visão estratégica, abrangente, integrada e flexível das políticas urbanas para o centro de São Paulo como um todo.

Finalmente, os deslocamentos de usos e de populações decorrentes do aumento do custo da moradia, do comércio e serviços, permite inferir uma intensificação da valorização imobiliária no entorno imediato do centro, onde se localiza a praça. Por outro lado, a pesquisa identificou que a concentração de casas noturnas e a característica boêmia da região, juntamente às atividades culturais presentes no entorno, provocaram uma mudança de público. Ambos os fatores ilustram a gentrificação: fenômeno relevante para a compreensão da ativação dos processos de resiliência no território da Roosevelt. Eles se apresentam sempre que se torna iminente a possibilidade de ruptura do caráter público da praça, de perda das garantias de livre circulação, de direito de permanência de usos e formas de apropriação existentes a priori.

A insurgência de novos atores, resultante das intervenções de regeneração urbana e demais adaptações feitas a posteriori, bem como a possibilidade de detectar novas fronteiras simbólicas entre os territórios gerados, demandam um refinamento dos conceitos abordados, de forma que permitam agregar às análises, novas variáveis que venham a surgir no curso da história da Praça, como antigas/ futuras formas de apropriações e usos, em especial, para a discussão da resiliência urbana. 


\section{Agradecimentos}

Este artigo é resultado da primeira etapa dos estudos produzidos em pesquisa de Doutorado vinculada ao Programa de Pós-Graduação em Arquitetura e Urbanismo (POSURB-ARQ) da Pontifícia Universidade Católica de Campinas, Brasil, financiada pela Bolsa Capacitação DRH PUC-Campinas 2018/2021.

\section{Referências bibliográficas}

Adger, W. N. (2003). Social and ecological resilience: are they related? Progress in Human Geography, 24(3), 347-364.

http://doi.org/10.1191/030913200701540465

Barata Salgueiro, T. (2005). Paisagens urbanas. Em C. A. Medeiros. Geografia de Portugal: Sociedade, paisagens e cidades (v. 2). Lisboa: Círculo de Leitores.

Barroca, B., DiNardo, M., e Mboumoua, I. (2013). De la vulnérabilité à la résilience: mutation ou bouleversement? EchoGéo, (24). https://doi.org/10.4000/echogeo.13439

Brandi, C. (2004). Teoria da restauração. Cotia: Ateliê.

Calliari, M. (2012). Praça Roosevelt: um espaço emblemático da relação de São Paulo com seus espaços públicos. Minha Cidade, 13(147.03). Recuperado de https://www.vitruvius.com.br/ revistas/read/minhacidade/13.147/4504
Cardozo, R. C. e Antunes Netto, A. A. (1970). Praça Roosevelt, São Paulo. Acrópole, 32(380), 11-20. Recuperado de http://www.acropole.fau.usp. br/edicao/380

Fantova, F. J. M. (2008). Resiliència i voluntad de sentit em la promoció de la salutpsico social em elsdocents: Capacitat de reconstrucció positiva a partir d'um context inicial d'adversitat. Estudi de cas em um institut d'educació secundària. (Tese de doutorado, não publicado). Barcelona, España.

Farias, J. A. (2017). Resiliência: um bom conceito para o projeto e a reforma urbana? Em C. D’Ottaviano e E. Nobre (Orgs.), XVII Encontro Nacional da Associação Nacional de Pós-Graduação e Pesquisa em Planejamento Urbano e Regional. São Paulo: Faculdade de Arquitetura e Urbanismo da Universidade de São Paulo. Recuperado de:

http://anpur.org.br/xviienanpur/principal/ publicacoes/XVII.ENANPUR Anais/ST Sessoes Tematicas/ST\%2010/ST\%2010.6/ST\%20 10.6-05.pdf

Fernandes da Cruz, F. (2015). Regeneração urbana de centros históricos: o caso do Alentejo Litoral (Dissertação de mestrado, não publicado). Universidade Nova de Lisboa, Lisboa.

Freestone, R. (2015). Urban planning (Western), History of. International Encyclopedia of the Social \& Behavioral Sciences (2a ed., pp. 862-868). Londres: Elsevier. https://doi.org/10.1016/ B978-0-08-097086-8.74015-3 
Gonçalves, C. (2016). Regiões, cidades e comunidades resilientes: novos princípios de desenvolvimento. urbe. Revista Brasileira de Gestão Urbana, 9(2), 371-385. https://doi.org/10.1590/21753369.009.002.aol

Guevara, T. (2015). Abordajes teóricos sobre las transformaciones sociales, económicas y territoriales en las ciudades latinoamericanas contemporáneas. EURE, 41(124), 5-24. https:// doi.org/10.4067/S0250-71612015000400001

Habitat III. (2015). 15 - Résilience urbaine. Recuperado de http://habitat3.org/wp-content/ uploads/15-Habitat-III-Issue-Paper-15 Resilience-urbaine.pdf

Harvey, D. (1992). A condição pós moderna. São Paulo, Loyola, 1992.

Holling, C. S. (1973). Resilience and stability of ecological systems. Annual Review of Ecology and Systematics, 4, 1-23 https://doi.org/10.1146/annurev.es.04.110173.000245

Holling, C. S. (2001). Understanding the complexity of economic, ecological, and social systems. Ecosystems, 4(5), 390-405. https://doi. org/10.1007/s10021-001-0101-5

Lacerda, F. (2019, 27 de novembro). Novos negócios hipster valorizam imóveis do centro de São Paulo. Folha de São Paulo. Recuperado de https://wwwl.folha.uol.com.br/mercado/2019/11/ novos-negocios-hipster-valorizam-imoveis-do-centro-de-sao-paulo.shtml

Levenstein, F. d. M. (2012). Praça Roosevelt, SP ou Brooklyn, NY? SP Escola de Teatro. Recuperado de https://www.spescoladeteatro.org.br/noticia/ praca-roosevelt-sp-ou-brooklyn-ny/

Maricato, E. (1996). Metrópole na periferia do capitalismo. São Paulo, Hucitec.

Mendes, L. (2013). A regeneração urbana na política de cidades: inflexão entre o fordismo e o pós fordismo. urbe. Revista Brasileira de Gestão Urbana, 5(1), 33-45. https://doi.org/10.7213/urbe.7784

Miranda, R. (2012, 7 de outubro). Skatistas e moradores debatem uso da praça Roosevelt. Folha de São Paulo. Recuperado de https://wwwl.folha. uol.com.br/saopaulo/2012/10/1164178-skatistas-e-moradores-debatem-uso-da-praca-roosevelt.shtml

Nesbitt, K. (2008). Uma nova agenda para a arquitetura: antologia teórica (1965-1995). São Paulo: Cosac Naify.

Ojeda, E. N. S. (2004). Introducción: resiliencia e subjetividad. En A. Melillo, E. N. S. Ojeda e D. Rodríguez (Orgs.), Resiliencia y subjetividad: Los ciclos de la vida (pp. 17-20). Buenos Aires: Paidós.

Operações Urbanas. (s. f.). Gestão Urbana SP. https://gestaourbana.prefeitura.sp.gov.br/ estruturacao-territorial/operacoes-urbanas/

Ou centro. $141^{a}$ Reunião ordinária da Comissão Executiva. (2017). Recuperado de https://www.prefeitura.sp.gov.br/cidade/ secretarias/upload/desenvolvimento urbano/sp urbanismo/arquivos/CE OUCentro 14la RO apresentacao 2017 05 29.pdf

Praça Franklin Roosevelt e entorno. (2009). Disponível em https://www.prefeitura.sp.gov.br/cidade/ secretarias/upload/desenvolvimento urbano/ 
sp urbanismo/arquivos/ouc/ouc apresentacao 78 roceouc.pdf

Prefeitura Municipal de São Paulo. (2004). Requalificação urbanística Praça Roosevelt. São Paulo: EMURB.

Schicchi, M. C. S. e Benfatti, D. M. (2004). Urbanismo: Dossiê São Paulo - Rio de Janeiro. Campinas: PUCCAMP/PROURB.

Silva, C. A. M. (2014). Em busca da Resiliência? Urbanização, ambiente e riscos em Santos (SP). (Tese de doutorado, não publicado). Universidade Estadual de Campinas, Instituto de Filosofia e Ciências Humanas, Campinas, Brasil.

Tallon, A. (2010). Urban regeneration in the UK. Routledge: Abingdon.

Toubin, M., Lhomme, S., Diab, Y., Serre, D., e Laganier, R. (2012). La résilience urbaine: un nouveau concept operation nelvecteur de durabilité urbaine? Développement Durable et Territoires, 3(1). https:// doi.org/10.4000/developpementdurable.9208

Vasquez, R. G. (2015). Luzes e sombras na trajetória dos Satyros. Sala Preta, 15(2). https://doi. org/10.11606/issn.2238-3867.v15i2p35-45

Yamashita, K. (2013). Praça Roosevelt, centro de São Paulo: intervenções urbanas e práticas culturais contemporâneas. (Dissertação de Mestrado, não publicado). Universidade de São Paulo, São Paulo, Brasil. 


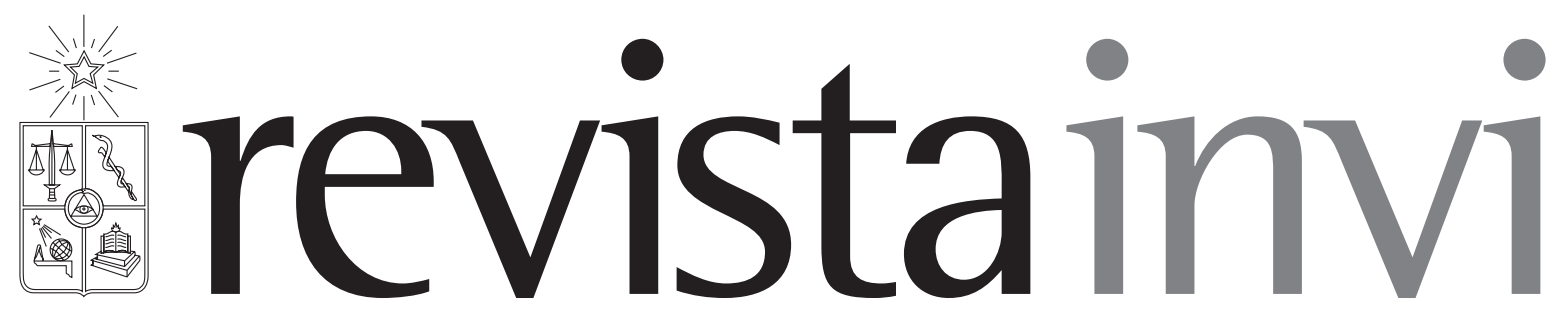

Revista INVI es una publicación periódica, editada por el Instituto de la Vivienda de la Facultad de Arquitectura y Urbanismo de la Universidad de Chile, creada en 1986 con el nombre de Boletín INVI. Es una revista académica con cobertura internacional que difunde los avances en el conocimiento sobre la vivienda, el hábitat residencial, los modos de vida y los estudios territoriales. Revista INVI publica contribuciones originales en español, inglés y portugués, privilegiando aquellas que proponen enfoques inter y multidisciplinares y que son resultado de investigaciones con financiamiento y patrocinio institucional. Se busca, con ello, contribuir al desarrollo del conocimiento científico sobre la vivienda, el hábitat y el territorio y aportar al debate público con publicaciones del más alto nivel académico.

Director: Dr. Ricardo Tapia Zarricueta, Universidad de Chile, Chile.

Editor: Dr. Luis Campos Medina, Universidad de Chile, Chile.

Editor asistente: Dr. Walter Imilan, Universidad de Chile, Chile.

Coeditora: Srta. Sandra Rivera, Universidad de Chile, Chile.

\section{COMITÉ EDITORIAL:}

Dr. Victor Delgadillo, Universidad Autónoma de la Ciudad de México, México.

Dra. María Mercedes Di Virgilio, CONICET/ IIGG, Universidad de Buenos Aires, Argentina.

Dra. Irene Molina, Uppsala Universitet, Suecia.

Dr. Gonzalo Lautaro Ojeda Ledesma, Universidad de Valparaíso, Chile.

Dra. Suzana Pasternak, Universidade de São Paulo, Brasil.

Dr. Javier Ruiz Sánchez, Universidad Politécnica de Madrid, España.

Dra. Elke Schlack Fuhrmann, Pontificia Universidad Católica de Chile, Chile.

Dr. Carlos Alberto Torres Tovar, Universidad Nacional de Colombia, Colombia.

Sitio web: http://www.revistainvi.uchile.cl/

Correo electrónico: revistainvi@uchilefau.cl

Licencia de este artículo: Creative Commons Atribución-Compartirlgual 4.0 Internacional (CC BY-SA 4.0) 